\title{
FAKTOR PENGHAMBAT DALAM PENEGAKAN QANUN JINAYAT DI ACEH
}

(Studi Kasus Penerapan Qanun No. 14 Tahun 2003 di Kota Subulussalam)

\author{
Ali Geno Berutu \\ Sekolah Pascasarjan (SPs) UIN Syarif Hidayatullah Jakarta \\ Email: ali_geno@ymail.com
}

\begin{abstract}
Abstrak
Tulisan ini membuktikan bahwa pelaksanaan Qanun Aceh No. 14 Tahun 2003 tentang khalwat di Kota Subulussalam belum sepenuhnya berjalan dengan baik. Banyak kendala yang dihadapi baik dari pelaksananya (pemerintah) maupun masyarakat sebagai objek hukum penerapan syariat Islam itu sendiri. Faktor hukum yang merupakan salah satu faktor utama penyebab stagnan-nya penindakan terhadap pelanggar Qanun No. 14 Tahun 2003 di Kota Subulussalam disamping faktor-faktor lainnya. Tulisan ini berusaha menguraikan kendala dalam efektivitas penegakan hukum yang merupakan suatu indikator penilaian terhadap penegakan suatu hukum, dalam artian untuk mengukur keberhasilan atau target yang telah ditetapkan dalam penerapan suatu hukum khususnya terhadap penegakan Qanun No. 14 Tahun 2003 di wilayah hukum Kota Subulussalam, Aceh.
\end{abstract}

Kata kunci: Khalwat, Aceh, Syariat Islam, Jinayat, Subulussalam

\begin{abstract}
This paper proves that the implementation of Qanun Aceh no. 14 of 2003 on khalwat in Subulussalam city has not fully run well. Many obstacles faced both from the executor (government) and the community as the object of the law of the application of Islamic Shari'a itself. The legal factor is one of the main factors causing its stagnant action against the violation of Qanun. 14 Year 2003 in Subulussalam City in addition to other factors. This paper attempts to outline the obstacles in the effectiveness of law enforcement which is an indicator of the assessment of the enforcement of a law, in order to measure the success or targets set in the application of a law especially to the enforcement of Qanun. 14 Year 2003 in the jurisdiction of Subulussalam City, Aceh.
\end{abstract}

Keywords: Khalwat, Aceh, Syariat Islam, Jinayat, Subulussalam 


\section{A. Pendahuluan}

Masyarakat Aceh memiliki corak kehidupan yang kental dengan agama Islam, hal ini dapat dilacak akar sejarah berdirinya kerajaan-kerajan Islam yang menjadi pusat kekuasaan politik sekaligus agama. Aceh tergolong wilayah yang memiliki sejarah panjang dalam hal kedatangan Islam dan berdirinya kerajaan-kerajaan Islam yang dimulai dari kerajaan Peureulak (840-1291), Samudra Pasai (1042-1427), Teumiang (840-1291), Darussalam (1205-1530) dan Aceh Darussalam (1514-1903) dan kerajaan - kerajaan kecil lainnya. ${ }^{1}$

Bila ditinjau dari sejarah kerajaan Aceh Darussalam (1514-1903) terdapat pemberlakuan hukum jinayat yang dipengaruhi oleh hukum adat. Pemberlakuan hukum jinayat ini dapat dibuktikan dengan adanya Qanun Meukuta Alam dan keteranganketerangan tentang praktek pemberlakuan hukum jinayat. ${ }^{2}$ Dalam Qanun Meukuta Alam ini ditetapkan bahwa dasar kerajaan Acceh Darussalam adalah Islam dan bentuknya adalah kerajaan yang bersuber kepada al-Qur'an, al-Hadist, Ijma' dan Qiyas. $^{3}$ Konsep ini sesungguhnya mencerminkan bahwa Islam dan negara adalah integral (al-Isla din wa daulah), tak berlebihan jika kemudian kerajaan Aceh Darussalam merumuskan Qanun al-Asyi sebagai pedoman dasar dalam kehidupan bernegaraa, sosial dan hukum masyarakat.

Meskipun Islam telah menjadi sumber undang-undang negara, tetapi tidak dapat dielakkan keterpengaruhan hukum jinayat yang diberlakukan oleh adat istiadat yang dipraktekkan di masyarakat. Dengan kata lain, pelanggaran terhadap pembunahan, perzinaan, pencurian dan khamar dikenakan sanksi yang tegas yang di ambil dari hukum jinayat yang bercampur dengan adat. Hal ini dapat disimpulkan bahwa adat orang Aceh sangat berpengaruh oleh ajaran Islam, bahkan lebih dari sekedar itu, adat orang Aceh terbentuk di atas kesadaran dan keinginan untuk menjalankan syariat Islam dalam kehidupan sehari-hari. ${ }^{4}$

Masyarakat Aceh memiliki strukur sosial tersendiri yang diatur berdasarkan hukum Qanun Meukuta Alam al-Asyi (Undang-undang kerajaan Aceh). Qanun tersebut menjelaskan bahwa kekuasaan tertinggi berada di tangan sultan, sedangkan kekuasaan agama berada

\footnotetext{
${ }^{1}$ Haedar Nasir, Islam syariat: Reproduksi Salapiyah Idiologis di Indonesia (Bandung: Mizan 2013), h. 336 .

2 Rusjdi Ali Muhammad, Revitalisasi Syari'at Islam di Aceh: Problem, Solusi dan Implementasi, (Ciputat: Logos Wacana Ilmu,2003), h. 49.

${ }^{3}$ Khamami Zada, "Sentuhan Adat Dalam Pemberlakuan Syariat Islam di Aceh (1514-1903)", Karsa, Vol. 20 No. 2, Desember 2012, h. 3.

4 Al Yasa' Abu Bakar," Islam, Hukam dan Masyarakat di Aceh Tajdid Syariat dalam Negara Bangsa", First International Conference of Aceh and Indian Ocean Studies, 24-27 Februari 2007, h. 2.
} 
ditangan ulama. Di bawah sultan ada Uleebalang (hulu balang) yang menguasai daerah tertentu dengan hak otonomi luas. Uleebalang membawahi beberapa imum mukim dan dibawah imum mukim terdapat beberapa keuchik. ${ }^{5}$

Di Aceh, syariat Islam di implementasikan secara formal setelah dikeluarkannya Undang-undang No. 44 Tahun 19996 tentang Penyelenggaraan Keistimewaan Provinsi Daerah Istimewa Aceh dan Undang-undang No. 18 Tahun 2001 tentang Otonomi Khusus bagi Provinsi Daerah Istimewa Aceh ${ }^{7}$ sebagai Provinsi Nanggroe Aceh Darussalam. Adanya legalitas dari pemerintah untuk menerapkan syariat Islam di Aceh direspon oleh pemerintah daerah dengan mengeluarkan beberapa peraturan daerah (Perda) dalam rangka terlaksananya syariat Islam di Aceh. Dari perda-perda itu selanjutnya dikembangkan lagi menjadi peraturan-peraturan daerah yang menyangkut tata laksana syariat Islam yang pada gilirannya melahirkan Qanun Aceh. ${ }^{8}$

Lima qanun disahkan antara tahun 2002-2004 yang berisi hukuman pidana atas pelanggaran syariah yakni: Qanun No. 11 Tahun 2002 tentang Penerapan Syariah Dalam Aspek Kepercayaan (aqidah), Ritual (ibadah), dan Penyebaran (syi'ar) Islam yang meliputi persyaratan busana islami; Qanun No. 12 Tahun 2003 tentang larangan Menkonsumsi dan Menjual Minuman ber-alkohol (khamar); Qanun No. 13 Tahun 2003 tentang larangan Judi (maisir); Qanun No. 14 Tahun 2003 melarang "perbuatan bersunyi-sunyian" (khalwat)9 dan Qanun No. 7 Tahun 2004 tentang Pembayaran Zakat.

Dari penjelasan latar belakang di atas, maka tulisan ini akan mencoba mengungkapkan faktor-faktor yang mempengaruhi implementasi Qanun No. 14 Tahun 2003 Tentang khalwat di Kota Subulussalam, baik foktor dari segi hukum maupun non hukum, sehingga dapat tergambar dengan jelas apa saja yang menjadi penghalang efektifitas Qanun No. 14 di di Kota Subulussalam dan di Aceh pada umumnya. Penelitian ini bersumber dari penelitian lapangan (field research) dan penelitian kepustakaan (library research) dengan metode kualitatif dan menggunakan pendekatan sosio-legal-historis.

${ }^{5}$ Hasan Basri, " A. Hasjmy (1914-1998) Kajian Sosial-Intlektual Pemikiran Tentang Politik Islam", (Disertasi Sps UIN Jakarta, 2008), h. 53. Lihat juga, Asma Uddin, "Religious Freedom Implications of Sharia Implementation in Aceh, Indonesia," University of St. Thomas Law Journal: Vol. 7: Iss. 3 (2010), Article Available at: http://ir.stthomas.edu/ustlj/vol7/iss3/8(diakses pada tanggal 02 Mei 2016) h. 618.

6 Haidar Nassir, Islam Syariat Reproduksi Salafiyah Idiologis di Indonesia (Bandung: Mizan, 2013),h. 332.

7 Topo Santoso, Membumikan Hukum Pidana Islam: Penegakan Syariat dalam Wacana dan Agenda, ( Jakarta: GIP, 2003),h. 106.

8 Syamsul Bahri, "Pelaksanaan Syariat Islam di Aceh Sebagai Bagian dari Wlayah NKRI", Jurnal Dinamika Hukum Vol. 12 No. 2 Mei 2012.

${ }_{9}$ Asma Uddin, "Religious Freedom Implications of Sharia ..., h. 632. 


\section{B. Pembahasan}

Ada banyak faktor yang mempengaruhi dalam efektivitas penegakan Qanun Kahalwat di Subulussalam. Merujuk kepada teori Soerjono Soekanto yang menjelaskan bahwa masalah pokok dalam penegakan hukum adalah terletak pada hukumnya sendiri (peraturan perundang-undangan yang berlaku), penegak hukumnya yakni pihak-pihak yang mengawal penerapan hukum, sarana atau fasilitas yang mendukung penerapan hukum, masyarakat di mana hukum tersebut diberlakukan dan budaya hukum dalam masyarakatnya. ${ }^{10}$ Kelima faktor tesebut saling memiliki kaitan yang erat dikarenakan esensi dari penegakan hukum. Kelima faktor tersebut merupakan tolak ukur daripada efektifitas penerapan hukum.

\section{Faktor Undang-undang (Qanun)}

Bila kita mengkaji Qanun Nomor 14 Tahun 2003 tentang khalwat, maka kita akan menemui suatu kepastian bentuk 'uqubat bagi mereka yang melanggar ketentuan-ketentuan khalwat di Aceh. Qanun ini tegas mengtakan bahwa perbuatan khalwat adalah haram, ${ }^{11}$ dan barang siapa yang melanggar ketentuan tersebut dapat di kenakan 'uqubat ta'zir berupa cambuk paling banyak 9 (sembilan) kali cambukan. ${ }^{12}$ Begitu juga dengan Qanun Nomor 6 Tahun 2014 tenntang hukum jinayat yang merupa pembaharu terhadap Qanun Nomor 14 Tahun 2003, dikatakan bahwa hukum berkhalwat adalah haram dan setiap orang yang melanggar ketentuan tersebut di ancam dengan 'uqubat ta'zir berupa cambuk sebanyak 10 (sepuluh kali) cambukan. ${ }^{13}$

Sebenarnya kelemahan utama yang terdapat dalam Qanun 14 tahun 2003 adalah tidak adanya kewenangan yang diberikan kepada wilayatul hisbah $(\mathrm{WH})^{14}$ untuk melakukan penahanan. WH tidak berwenang menahan dan memeriksa, sehingga penahanan yang dilakukan WH merupakan tindakan melanggar ketentuan hukum dan

10 Soerjono Soekanto, Faktor-Faktor yang Mempengaruhi Penegakan Hukum (Jakarta: PT. Raja Grafindo Persada, 2008), h. 8. Lihat juga, Jainuddin Ali, Sosiologi Hukum (Jakarta: Sinar Grafika, 2007), h. 62 .

11 Pasal 4 Qanun Nomor 14 Tahun 2003 Tentang Khalwat. Lihat juga Zulkarnain Lubis, Menyambut Qanun Jinayah Nomor 6 Tahun 2014, https://drive. google. com/file/d/0B5UQVc I8Df8WenBNSWNfZU VMcTQ/view? pli=1 (diakses 20 Oktober 2015).

12 Pasal 22 Qanun Nomor 14 Tahun 2003 Tentang Khalwat.

13 Pasal 23 ayat (1) Qanun Nomor 6 Tahun 2014 Tentang Hukum Jinayat.

14 Wilayatul Hisbah adalah lembaga atau badan yang berwenang memberitahukan kepada masyarakat tentang peraturan-peraturan yang sudah berlaku dan menyadarkan anggota masyarakat tersebut, agar mematuhi aturan-aturan supaya tidak dikenakan sanksi atau denda dari peraturanperaturan terebut (law enforcement). Lihat, Al Yasa' Abu Bakar, Wilayatul Hisbah, Polisi Pamong Praja Dengan Kewenangan Khusus di Aceh, (Banda Aceh: Dinas Syari'at Islam Aceh, 2009), h. 22. 
melampaui batas kewenangan. Kewenangan yang dimiliki WH hanya sebatas melakukan pengawasan terhadap penegakan syariah Islam sekaligus melakukan pembinaan terhadap para pelanggar syariah Islam yang sedang berlaku di Aceh. Dan tidak ada kewenangan WH melakukan penahanan terhadap para pelanggar pelaku Syariah di Aceh bila berdasarkan kepada Qanun Nomor 14 Tahun 2003.15 Apabila WH menangkap pelaku pelanggaran khalwat akan dilimpahkan perkaranya ke pihak penyidik di kepolisian, dan pihak kepolisianlah yang berwenang melakukan penahanan terhadap mereka. ${ }^{16}$

Setelah di sahkannya Qanun Nomor 7 Tahun 2013 Tentang Hukum Acara Jinayat sepertinya telah memberi angin segar bagi penegakan syariat Islam di Aceh. Hal ini ditandai dengan penambahan kewenangan yang diberikan kepada Wilayatul Hisbah dalam melakukan tindakan yang nyata terhadap penegakan Qanun Jinayat di Aceh, dimana pada qanun-qanu sebelumnya (Qanun 12, 13 dan 14 Tahun 2003) kewenangan WH hanya berupa pengawsan terhadap pemberlakuan syariat Islam di Aceh. Sebagai mana di jelaskan dalam Pasal 7 dan 9 Qanun 2013 sebagai berikut:

Penyelidik merupakan Pejabat Polri dan PPNS yang telah diberi wewenang oleh Undang-Undang dan/atau Qanun untuk melakukan penyelidikan (Pasal 6).

Dalam Pasal 7 dan pasal 9 ayat (2) dijelaskan:

(1) Penyelidik sebagaimana dimaksud dalam Pasal 6, karena kewajibannya berwenang:

a. menerima laporan atau pengaduan dari seseorang tentang adanya Jarimah;

b. mencari keterangan dan barang bukti;

c. menyuruh berhenti seseorang yang dicurigai dan menanyakan serta memeriksa tanda pengenal diri; dan

d. mengadakan tindakan lain menurut hukum secara bertanggung jawab dan sesuai dengan prinsip-prinsip Syariat Islam.

(2) Penyelidik sebagaimana dimaksud dalam Pasal 6, atas perintah penyidik dapat melakukan tindakan:

a. penangkapan, larangan meninggalkan tempat, penggeledahan dan penyitaan;

b. pemeriksaan dan penyitaan surat;

c. mengambil sidik jari dan memotret seseorang; dan/atau

d. membawa dan menghadapkan seseorang kepada penyidik.

15 Wawancara dengan Sarkani, Kasi Ketentraman dan Ketertiban Pol PP dan WH Kota Subulussalam, 23 April 2015.

16 Keputusan Gubernur Aceh No. 01 tahun 2004 tentang kewenangan pembentukan Organisasi Wilayatul Hisbah. 
(3) Penyelidik membuat dan menyampaikan laporan hasil pelaksanaan tindakan sebagaimana dimaksud pada ayat (1) dan ayat (2) kepada Penyidik.

Pasal 9 Ayat (2):

(2) Penyidik PPNS sebagaimana dimaksud dalam Pasal 8 ayat (1) huruf $b$, berwenang:

a. menerima laporan atau pengaduan dari seseorang tentang adanya tindak pidana pelanggaran Qanun dan/atau Peraturan Perundang-undangan lainnya;

b. melakukan tindakan pertama di Tempat Kejadian Perkara (TKP) dan melakukan pemeriksaan;

c. menyuruh berhenti seorang Tersangka dan memeriksa tanda pengenal diri Tersangka;

d. melakukan pengeledahan, penangkapan, dan penahanan;

e. melakukan penyitaan benda dan/atau surat sesuai dengan Peraturan Perundang-undangan;

f. mengambil sidik jari dan memotret seorang Tersangka;

g. memanggil orang untuk didengar dan diperiksa sebagai Tersangka atau Saksi;

h. mendatangkan Saksi ahli yang diperlukan dalam hubungannya dengan pemeriksaan perkara;

i. membuat Surat Perintah Dimulainya Penyidikan (SPDP) kepada Penuntut Umum dengan tembusan kepada korwas PPNS setelah terlebih dahulu berkoordinasi dengan korwas;

j. melakukan penghentian penyidikan setelah berkoordinasi dengan penuntut umum bahwa tidak terdapat cukup bukti atau peristiwa tersebut bukan merupakan tindak pidana dan tembusannya disampaikan kepada Korwas PPNS dan selanjutnya memberitahukan hal tersebut kepada Tersangka atau kuasanya; dan/atau

k. mengadakan tindakan lain sesuai dengan Peraturan Perundang-undangan.

(3) Dalam melaksanakan kewenangan sebagaimana dimaksud pada ayat (1) dan ayat (2) penyidik wajib menjunjung tinggi nilai-nilai Syariat Islam dan Peraturan Perundangundangan.

PPNS dalam melaksanakan kewenangan penyelidikan sebagimana dimaksud dalam Pasal 7 dan Pasal 9 ayat (2) dibantu oleh anggota kepolisian dan polisi WH.17 Inilah yang menjadi dasar bagi WH dalam melakukan penahan terhadap setiap orang yang melanggar

17 Pasal 10 Qanun Nomor 7 Tahun 2013 Tentang Hukum Acara Jinayat. 
ketentuan-ketentuan qanun jina>ya>t di Aceh, dimana ketentuan seperti ini sebelumya tidak pernah di atur dalam qanun-qanun jinayat terdahulu (Qanun 12, 13 dan 14 Tahun 2003). Jadi kendala yang selama ini menjadi alasan utama bagi WH dalam menindak pelaku jinayat di Aceh sudah terjawab dengan disahkannya Qanun No. 7 Tahun 2013 Tentang Hukum Acara Jinayat.

Kendala selanjutnya adalah adanya benturan antara qanun dalam penanganan kasus khalwat. Permasalahan khalwat di Aceh, selain di atur dalam Qanun Nomor 14 Tahun 2003 dan ditegaskan kemabali dalam Qanun Nomor 6 Tahun 2014 juga di atur dan menjadi salah satu kewenangan dari peradilan adat di Aceh, hal ini di jelaskan dalam Qanun Nomor 9 Tahun 2008 Tentang Pembinaan Kehidupan Adat dan Adat Istiadat. Dalam Pasal 13 ayat (1) dijelaskan bahwa khalwat merupakan salah satu dari 18 kewenangan yang di berikan kepada mahkamah adat di Aceh. Hal inilah yang menjadi celah permasalahan baru dalam penerapan Qanun Khalwat di Aceh dan khususnya Kota Subulussalam.

Dengan adanya Qanun Nomor 9 Tahun 2008, setiap pelanggaran khalwat yang terjadi Aceh harus diselesaikan melalui peradilan adat terlebih dahulu. Apabila bisa diselesaikan dalam peradilan adat, maka pihak berwenang dalam hal ini WH tidak berwenang lagi untuk menindaklanjuti kasus tersebut. ${ }^{18}$ Mengenai mekanisme penyelesaian kasus khalwat di lembaga adat akan disesuaikan dengan kebiasaan adat di wilayah masyarakat setempat, bararti hukum adat di Aceh tidak memiliki standar tertentu dalam mekasnisme penyelesaiannya, hal ini dikarenakan masyarakat Aceh yang majemuk dan terdiri dari beberapa suku yang berbeda. ${ }^{19}$

Adanya dualisme lembaga dalam peneyelesaian kasus khalwat di Aceh merupakan kendala tersendiri bagi WH dalam menegakkan Qanu Khalwat. Satu penelitian terkait dengan khalwat/mesum di kota Lhokseumawe yang dilakukan Abdullah, seorang dosen Sekolah Tinggi Agama Islam Negeri (STAIN) Lhokseumawe menyebutkan, berkurangnya penyelesaian kasus khalwat/mesum melalui WH dan mahkamah syar'iyah dikarena penyelesaian kasus khalwat/mesum telah bergeser. Kasus khalwat/mesum saat ini lebih mengutamakan penyelesaian secara adat ketimbang kepada jalur WH dan mahkamah syar'iyah.

18 Wawancara dengan Kalidin, Kasi Penegakan Syariat Islam, WH Kota Subulussalam, 23 April 2015.

19 Putri Sahadat Bancin, Penyelesaian Tindak Pidana Khalwat/Mesum Berdasarkan Qanun Nomor 14 Tahun 2003 (Suatu Penelitian Di Kota Subulussalam), (Banda Aceh: Skripsi Fak. Hukum Univ. Syiah Kuala, 2015), h. 55. 
Hasil penelitian itu telah dipaparkan dalam Aceh Development International Conference (ADIC) yang berlangsung pada 27 Maret 2013 di Kuala Lumpur. Apa yang disimpulkan Abdullah, barangkali ada benarnya. Sebab sejak Majelis Adat Aceh ${ }^{20}$ (MAA) melakukan sosialisasi penyelesaian kasus masyarakat melalui adat dalam beberapa tahun terakhir, maka kasus-kasus yang masuk dalam kategori 18 kasus adat sesuai dengan amanah Qanun Nomor 9 Tahun 2008, bisa diselesaikan melalui mahkamah adat di gampong ataupun mukim..$^{21}$

Untuk mengatasi hal tersebut, sudah saatnya para pemangku kepentingan untuk duduk bersama dan merumuskan mekanisme penyelesaian kasus khalwat di Aceh, khususnya di Subulussalam. Hal ini penting dilakukan guna mempertegas mengenai ketentuan-ketentuan khalwat seperti apa yang menjadi wilayah kewenangan masing-masing lembaga. Karena selama ini penangangan kasus khalwat menurun penyelesaiannya di tingkat mahkamah syar'iyah. Disamping itu ada yang beranggapan bahwa hukuman ${ }^{22}$ yang diberikan lembaga adat terhadap pelaku khalwat di nilai kurang adil, karena bentuk hukumannya kurang begitu tegas dan tidak menimbulkan efek jera bagi para pelakunya.

Di Kota Subulussalam sendiri penyelesaian kasus khalwat di tempuh dengan jalur kekeluargaan. Sebagaimana yang dijelaskan Kasi Penegak Kebijakan Daearah Dan Syariat Islam Kota Subulussalam bahwa, setiap pelanggaran kasus khalwat diwilayah hukum Kota Subulussalam terlebih dahulu dilakukan penyelesaian dengan cara kekeluargaan dan adat istiadat yang berlaku di Subulussalam. Setelah pihak Satpol PP dan WH memberikan teguran dan peringatan kepada para pihak yang melanggar qanun tentang khalwat tersebut, lalu menyerahkannya kepada geucik (kepala desa) untuk diselesaikan secara adat dan aturan kampong tersebut, setelah dilakukan proses hukum adat tapi belum menghasilkan suatu

${ }^{20}$ Di Aceh disamping adanya lembaga hukum formal yang menangani pelanggaran syariat Islam, juga terdapat lembaga informal yaitu lembaga adat yang sangat berpengaruh pada pola kehidupan masyarakat Aceh. Lembaga adat memiliki landasan hukum yakni Qanun No. 9 Tahun 2008 tentan Pembinaan Kehidupan Adat dan Adat Istiadat serta Qanun Nomor 10 Tahun 2008 tentang Lembaga Adat.

${ }^{21}$ Teuku Muttaqin Mansur, "Penyelesaian Kasus Mesum Melalui Mahkamah Adat atau Mahkamah Syar'iyah?", http://aceh.tribunnews.com/2013/09/04 /peny elesaian-kasus-mesummelalui-ma-atau-ms?page3 (dikases pada tanggal 24 Agustus 2015).

22 Pasal 16 (1) Qanun Nomor 9 Tahun 2008 dijelaskan bahwa jenis-jenis sanksi yang dapat dijatuhkan dalam penyelesaian sengketa adat sebagai berikut: nasehat; teguran; pernyataan maaf; sayam; diyat; denda; ganti kerugian; dikucilkan oleh masyarakat gampong atau nama lain; dikeluarkan dari masyarakat gampong atau nama lain; pencabutan gelar adat; dan bentuk sanksi lainnya sesuai dengan adat setempat. 
kesepakatan, baru diselesaikan secara qanun yang berlaku. ${ }^{23}$ Pada dasarnya penyelesaian kasus khalwat ditempuh dengan jalan damai dimana kedua keluarga yang tersangka khalwat/mesum duduk bersama untuk mencari solusi terhadap penyelesaian kasus tersebut dengan hukumuan yang sering di capai adalah berupa pemberian nasehat, perdamaian, pernyataan maaf, ganti rugi/denda dan di nikahkan. ${ }^{24}$

\section{Faktor Penegak Hukum}

Penegak hukum dilakukan oleh institusi yang diberi wewenang untuk itu (penegakan qanun syariat Islam), dalan hal ini adalah wilayatul hisbah. Sejak hukum itu mengandung perintah dan pemaksaan, maka sejak itu pula hukum membutuhkan bantuan untuk mewujudkan perintah tersebut. Hukum menjadi tidak ada artinya, bila perintahnya tidak dapat dilaksanakan. Karena itu, diperlukan usaha dan tindakan manusia agar perintah dan paksaan yang secara potensial ada di dalam peraturan itu menjadi nyata dalam praktek hukum. Donald Black, sebagaimana dikutip Sadjipto Rahardjo mengatakan bahwa dimensi keterlibatan manusia dalam penegakan hukum tersebut dinamakan dengan mobilisasi hukum. Dalam mobilisasi hukum inilah manusia turut campur sehingga hukum tidak hanya mengancam dan berjanji di atas kertas. ${ }^{25}$

Wilayatul Hisbah dan Sat Pol PP Kota Subulussalam saat ini memiliki 139 orang anggota dan keseluruhan dari anggota tersebut berpusat di Kantor Pol PP dan WH Kota Subulussalam di Subulussalam. Adapun status dari 139 orang anggota tersebut, baru 15 orang yang diangkat menjadi pegawai negeri sipil (PNS) dan sisanya masih berstatus sebagai pegawai honorer. ${ }^{26}$ Selain itu WH Kota Subulussalam juga belum mempunyai Penyidik Pegawai Negeri Sipil (PPNS), padahal keberadaan PPNS ini sangat di butuhkan guna untuk proses penyelidikan dan penyidikan yang dilakukan $\mathrm{WH}$ terhadap pelaku pelanggaran qanun jinayat di Kota Subulussalam.

Ketersediaan sumber daya manusia yang memadai sangat mempengaruhi efektivitas suatu hukum. Berdasarkan keterangan di atas bahwa saat ini Wilayatul Hisbah dan Pol PP Kota Subulussalam memiliki 139 anggota dimana 15 belas di antaranya adalah PNS, sisanya pengawai honorer yang kebayakan memiliki latar belakang pendidikan Sekolah Menengah

${ }^{23}$ Wawancara dengan Bapak Kalidin, Kasie Penegak Kebijakan Daearah Dan Syariat Islam Kota Subulussalam. Kantor Satuan Polisis Pamong Praja dan Wilayatul Hisbah Kota Subulussalam, pada tanggal 23 April 2015.

${ }^{24}$ Wawancara dengan H.M Layari Kombih, selaku Ketua Majelis Adat Aceh (MAA) Kota Subulussalam, bertempat dikantor MAA Kota Subulussalam pada tanggal 27 April 2015.

${ }^{25}$ Danial, "Efektifitas ‘Uqūbat Dalam Qanun No. 14 Tahun 2003 dan DQHR Tentang Khalwat dan Ikhtilath", Jurnal Asy-Syir'ah Vol. 45, No. I, 2011, h. 1004.

${ }^{26}$ Wawancara dengan Abdul Malik, selaku Kepala Satpol PP dan WH Kota Subulussalam. 
Atas (SMA).27 Pendidikan para penegak hukum ini (WH) sangat vital dalam penegakan hukum syariah di Aceh, karena hukum yang akan di tegakkan nantinya bukanlah hukum yang berdasarkan kepada UUD sebaggai landasar utama pembuatan hukumnya, akan tetapi al-Qur'an dan al-Hadist. Maka untuk itu setiap anggota WH di tuntut untuk memiliki kecapan dalam bidang hukum Islam (fikih). Inilah yang menjadi permaslahan selama ini, dimana masyarakat menilai, para penegak hukum syariah di Kota Subulussalam belum layak untuk dijadikan sebagai penegak qanun jinayat. Hal ini dikarenakan sikap dan perilaku keseharian anggota WH yang belum mencerminkan nilai-nilai ke-Islaman dalam kehidupan masyarakat sehari-hari di luar masa tugasnya. ${ }^{28}$

Memang dalam perekrutan anggota WH selam ini belum ada standar yang khusus mengenai latar belakang pendidikan bagi anggota WH. Menurut Wildan Sastra selaku pemerhati syariat Islam dan gender kota Subulussalam, mengkritik bahwa sudah seharusnya WH Kota Subulussalam membuat standar khusus dalam perekrutan anggota WH dimana dinai-nilai ke-Islaman harus menjadi standar utama dalam perekerutan tersebut, sehingga dalam penegakan qanun-qanun syariat anggota $\mathrm{WH}$ bisa mengetahui dengan baik dan benar apa yang menjadi tugasnya dan begitu juga dalam kehidupan bermasyarakat sehari-hari, anggota WH di harapkan bisa memberikan contoh yang nyata kepada masyarakat akan perlunya menegakkan syariat Islam di Kota Subulussalam. Wildan mengatakan, anggota WH seharusnya menjadi garda terdepan dalam penegakan dan pencotohan syariat Islam bukan malah sebaliknya. ${ }^{29}$

\section{Faktor Fasilitas Penunjang Penegakan Hukum}

Keterpusatan WH di Kota Subulussalam sebenarnya menjadi masalah tersendiri terhadap penegakan qanun jinayat di Subulusslam. Saat ini Kota Subulussalam memiliki 5 kecamatan yang terdiri dari Kecamatan Simpang Kiri, Penanggalan, Sultan Daulad, Runding dan Longkib. Tiga dari lima kecamatan ini pada dasarnya jauh dari Kantor Pol PP dan WH Kota Subulussalam yang terletak di pusat Pemerintahan Kota Subulussalam di Kecamatan Simpang Kiri. Ketiga kecamatan tersebut adalah, Kecamatan Sultan Daulad, Kecamatan Rundeng dan Kecamatan Longkib. Sedangkan dua lainnya yakni Kecamatan Simpang Kiri dan Kecamatan Penanggalan relatif berdekatan. Maka tidak heran bila selama ini kasus yang di tangani WH Kota Subulussalam berasal dari Kecamatan Simpang Kiri dan

27 Wawancara dengan Bambang Aprianto, Selaku Subag TU Pol PP dan WH Kota Subulussalam.

28 Wawancara dengan Arifin Sarbaini, selaku Ketua FPI Kota Subulussalam.

29 Wawancara dengan Wildan Sastra, selaku pemerhati syariat Islam di Kota Subulussalam. 
Kecamatan Penanggalan, karena dua kecamatan inilah yang paling memungkinkan untuk dilakukan pengontrolan setiap saat, karena letak dan jaraknya dari kantor Pol PP dan WH tidak terlalu jauh.

Keberadaan Kantor WH seharusnya tidak hanya berada di satu titik tertentu, tapi harus ada di setiap kecamatan-kecamatan di Kota Subulusssalam. Hal ini dilakukan supaya keberadaan WH dapat dirasakan langsung oleh masyarakat bukan hanya sebagai simbol dari pelengkap lembaga-lembaga daerah di Aceh. Dalam Keputusan Gubernur No. 1 Tahun 2004 Tentang Pembentukan Organisasi dan Tata Kerja Wilayatul Hisbah disebutkan bahwa susunan organisasi Wilayatul Hisbah, terdiri atas; Wilayatul Hisbah Tingkat Provinsi; Wilayatul Hisbah Tingkat Kabupaten/Kota; Wilayatul Hisbah Tingkat Kecamatan, dan Wilayatul Hisbah Tingkat Kemukiman. ${ }^{30}$ Berarti pembentukan kantor WH di setiap kecamatan sangat mungkin untuk di bentuk karena telah mempunyai landasan hukum yang kuat.

Ketika penulis menanyakan hal tersebut, Kepala Satuan Polisi Pamong Praja dan Wilayatul Hisbah Kota Subulussalam Bapak Abdul Malik mengatakan, hal itu mungkin saja dilakukan tapi tidak dalam waktu dekat ini, karena menurut Abdul Malik saat ini Pol PP dan WH masih berfokus kepada kelengkapan fasilitas penunjang lainnya yang menurutnya sangat belum memadai/ideal untuk sebuah kantor WH tingkat kota di Aceh. Selain itu, Kantor WH kota Subulussalam sekarang ini juga belum memiliki kantor yang permanen tapi masih dalam bentuk sewa yang dilakukan oleh Pemerintah Kota Subulussalam. Memang inilah kendala utama mengapa WH kota Subulussalam belum membentuk kantor WH di tingkat kecamatan, karena semua itu tentunya membutuhkan anggaran yang tidak sedikit.

Alokasi anggaran yang disediakan APBK Kota Subulussalam terhadap Kantor Satpol PP dan WH memang sangat terbatas. Sebagai gambaran, pada tahun 2013 Pol PP dan WH mendapat alokasi anggaran sebesar Rp. 4.215.000.000,00 (empat milyar dua ratus lima belas juta rupiah) sedangkan pada tahun 2014 alokasi anggaran Pol PP dan WH adalah Rp. 4.300.000.000,00 (empat milyar tiga ratus juta rupiah) dan pada tahun 2015 alokasi anggaran yang disediakan adalah Rp. 4.350.000.000,00 (empat milyar tiga ratus lima puluh juta rupiah). Dengan anggaran tersebut WH dikatakan Abdul Malik belum bisa berbuat banyak mengenai pengawasan syariat Islam di Kota Subulussalam, belum lagi wilayah

${ }^{30}$ Hirwan Jack, "Efektivitas Wilayatul Hisbah Dalam Pencegahan Aliran Sesat Di Aceh", http://bkpp.acehprov .go.id/ simp egbrr /Art ikel/Artikel05-02-2015/Wilayatul H is bah_Aceh.pdf ,h. 2. (diakses pada tanggal 16/03/2015). 
subulussalam yang menjadi daerah tugasnya juga luas dan berjauhan antar satu kecamatan dengan kecamatan yang lainnya. Untuk saat ini Pol PP dan WH Kota Subulussalam memiliki bebera fasilitas untuk keperluan dinas seperti, satu buah kenderaan mobil patroli, 16 (enam belas) kenderaan sepada motor, 8 (delapan) koputer/laptop. ${ }^{31}$

Dengan anggaran dan fasilitas seperti itu, bisa di bayangkan bagaimana proses pengawasan yang di lakukan oleh WH Kota Subulussalam terhadap qanun-qanun syariat Islam Kota Subulussalam, belum lagi status anggota WH yang mayoritas masih sebagai pegawai honorer, tentu hal ini juga bisa mempengaruhi konsentrasi mereka dalam menjalankan tugasnya sehari-hari. Memang dalam hal ini, keseriusan Pemerintahan Kota Subulussalam dalam menerapkan syariat Islam masih sangat mungkin untuk dipertanyakan, pemerintah seharusnya sepenuh hati dalam menerapkan syariat Islam di kota ini dengan menyediakan alokasi anggaran untuk WH yang memadai. Maka wajar saja kalau selama ini banyak kalangan yang menilai proses penerapan syariat Islam di Kota Subulusssalam masih satgnan dan jalan di tempat. Belum lagi ketiadaan Mahkamah Syar'iyah Kota Subulussalam, karena saat ini Mahkamah Syar'iyah Kota Subulussalam masih menginduk kepada Mahkamah Syar'iyah Singkil di Kabupaten Aceh Singkil.

Maka wajar-wajar saja jika selama ini kasus khalwat, maisir maupun khamar hanya di tindak di sekitar wilayah Kecamatan Simpang Kiri dan Penanggalan, karena kedua kecamatan tersebut merupakan berdekatan dengan kantor WH yang tersentral di Simpang Kiri Kota Subulussalam. Hal ini dapat di lihat dari data tempat terjadinya pelanggaran Qanun 12, 13 dan 14 Tahun 2003 yang di miliki oleh Kantor Satpoll PP dan WH Kota Subulussalam sebagai berkut:

\section{Tabel}

Lokasi Tempat Pelanggaran Qanun Nomor 12, 13 dan 14 di Kecamatan Simpang Kiri dan Penanggalan

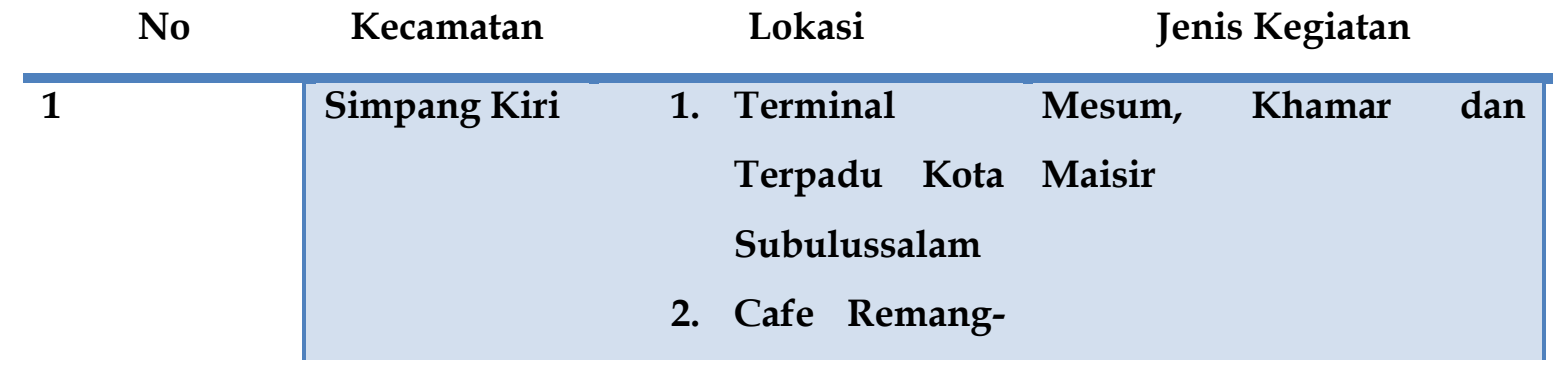

31 Wawancara dengan Bambang Aprianto, Selaku Subag TU Pol PP dan WH Kota Subulussalam. 


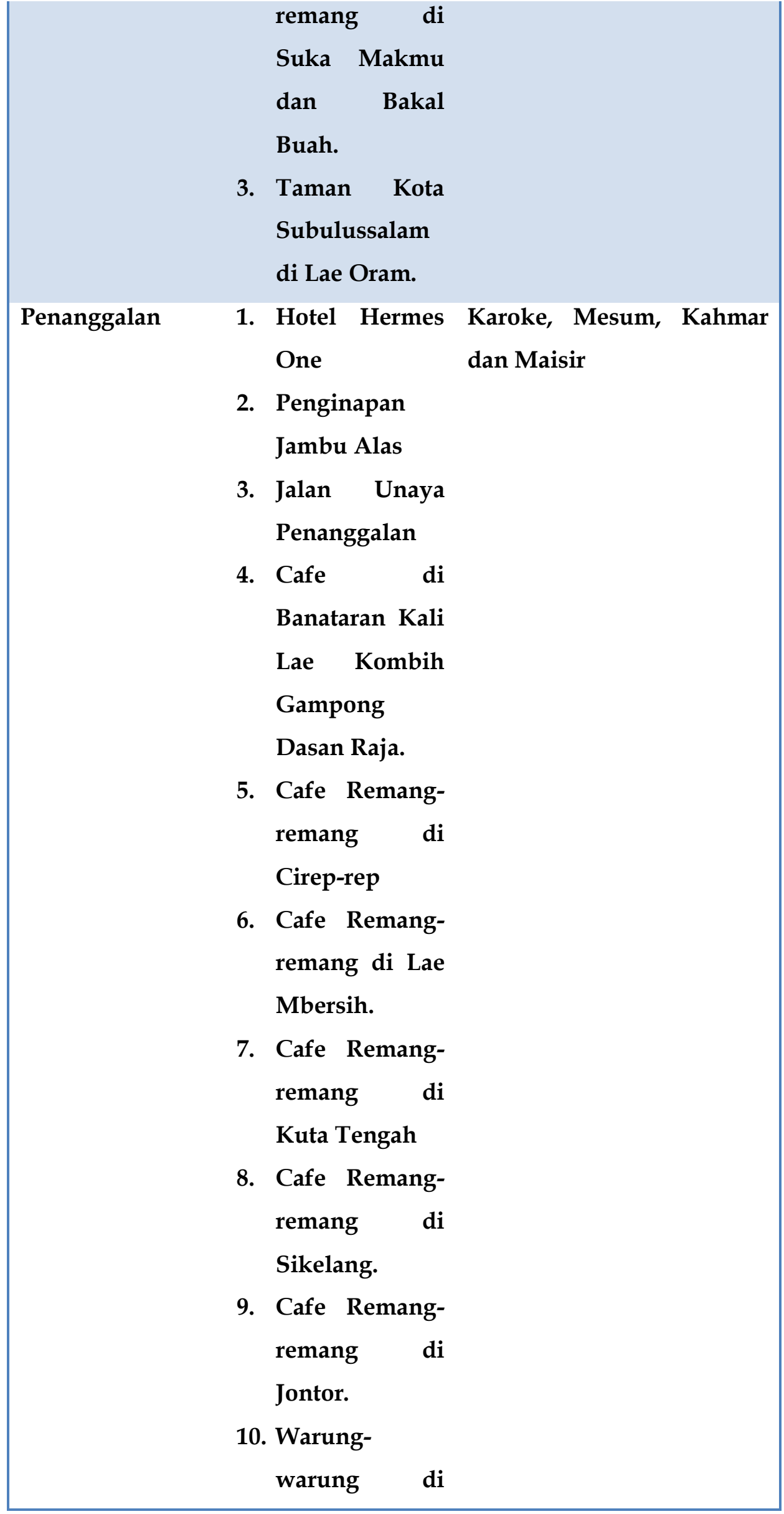




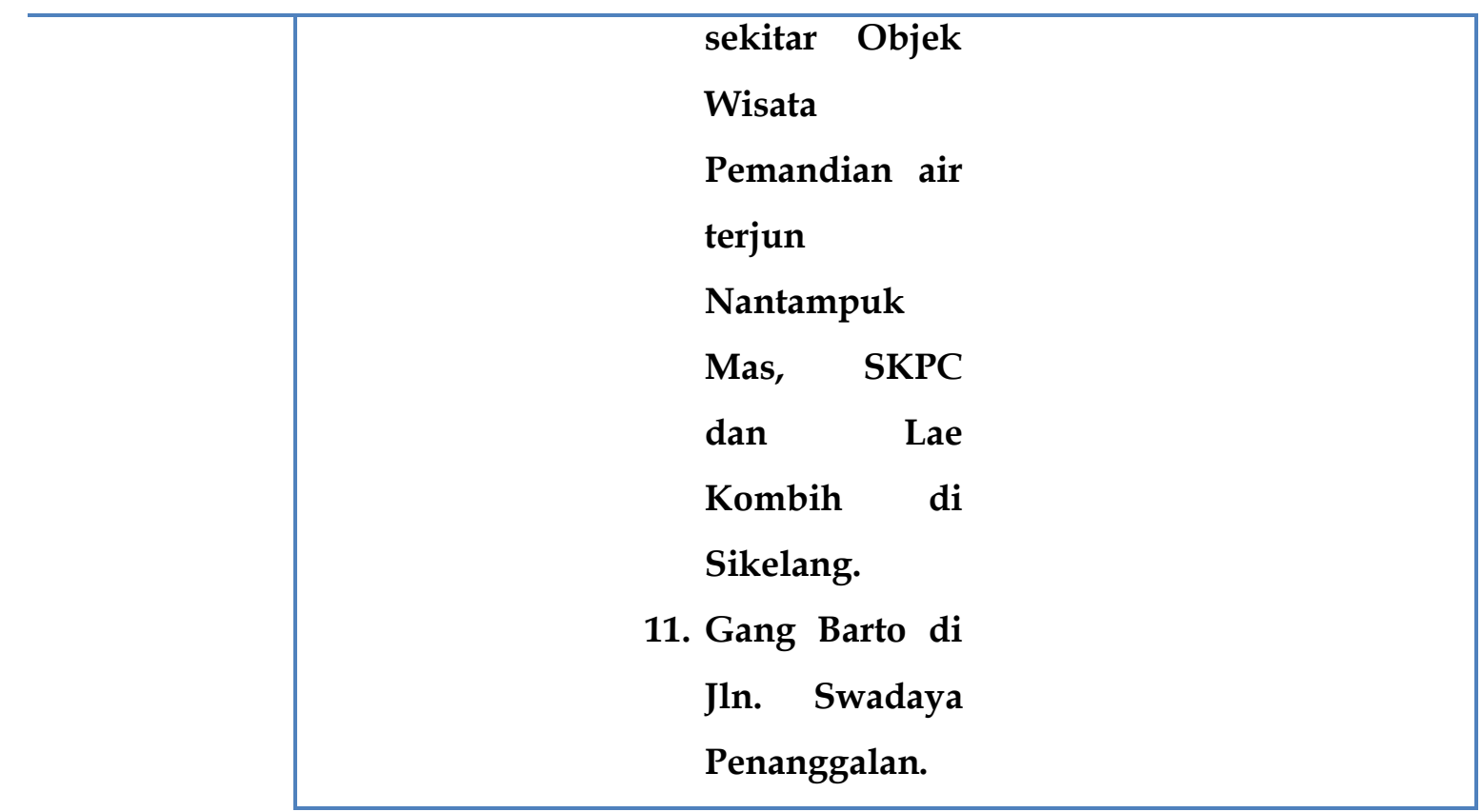

*Berdasarkan data dari Kantor Pol PP dan WH Kota Subulussalam tahun 2015.

\section{Faktor Kesadaran Hukum Masyarakat Yang Masih Rendah}

Kesadaran hukum masyarakat secara umum masih rendah. Sebagian warga masyarakat menganggap kewajiban taat pada syariat Islam merupakan beban yang memberatkan. Perasaan terbebani ini di samping dipengaruhi oleh kondisi sosial ekonomi yang sulit, juga karena sifat masyarakat lokal berlakunya qanun-qanun jinayat di Subulussalam. Kondisi sosial ekonomi yang sulit banyak berpengaruh pada terjadinya tindak pidana perjudian, perdagangan miras, prostitusi dan lain-lain.

Keterlibatan masyarakat dalam mengawal Qanun Khalwat sangat mempengaruhi efektivitas pemeberlakuan qanun tersebut. Dengan segala keterbatsan yang dimiliki oleh WH Kota Subulussalam, keterlibatan aktif masyarakat sangat di butuhkan, karena bagaimanpun juga perbuatan pelanggaran qanun khalwat dilakukan dan terjadi di tengahtengah kalangan masyarakat Kota Subulussalam. Mengingat pentingnya peran dan kesadaran hukum masyarakat ini, Qanun Nomor 14 Tahun 2003 jauh-jauh hari telah memberikan ruang berupa peran aktif masyarakat dalam mengawal pemberlakuan qanun ini, seperti yang di jelaskan dalam BAB IV Pasal 8-12 sebagai berikut:

Masyarakat berperanserta dalam membantu upaya pencegahan dan pemberantasan perbuatan khalwat/mesum; Masyarakat wajib melapor kepada pejabat yang berwenang baik secara lisan maupun tulisan apabila mengetahui adanya pelanggaran terhadap larangan khalwat/mesum; Dalam hal pelaku pelanggaran tertangkap tangan oleh warga masyarakat, maka pelaku beserta barang bukti segera diserahkan kepada pejabat yang berwenang; Pejabat yang berwenang wajib memberikan perlindungan dan jaminan keamanan kepada pelapor sebagaimana dimaksud dalam 
pasal 8 dan/atau orang yang menyerahkan pelaku sebagaimana dimaksud dalam pasal 9; Warga masyarakat dapat menuntut pejabat yang berwenang sebagaimana dimaksud dalam pasal 9 apabila lalai memberikan perlindungan dan jaminan keamanan bagi pelapor dan/atau orang yang menyerahkan pelaku; Tata cara penuntutan sebagaimana dimaksud dalam pasal 11 dilakukan sesuai peraturan perundang-undangan yang berlaku dan diajukan ke mahkamah.

Kesadaran dan pengetahuan tentang qanun inilah yang dirasa masih kurang di tengah-tengah masyarakat. Di beberapa tempat, seperti Sultan Daulad, Runding dan Penanggalan, ketika penulis berdiskusi dengan masyarakat dan pemuda setempat mengatakan, tindak pelanggaran terhadap qanun jinayat, khususnya qanun 14/2003 sebenarnya sangat sering terjadi di daerah mereka masing-masing, masyarakat juga sudah merasa bosan untuk selalu mengingatkan bahwa perbuatan mereka bertentangan dengan qanun jinayat di Aceh. Pada akhirnya masyarakatpun cuek dan berharap petugas $\mathrm{WH}$ melakukan patroli ke wilayah mereka. ${ }^{32}$

Sebenarnaya apabila kita memperhatikan Pasal 8-12 Qanun No. 14 Tahun 2003, seharusnya tidak ada lagi keraguan bagi masyarakat untuk melaporkan setiap orang yang melanggar ketentuan Qanun 14/2003. Karena dalam Pasal 10 dijelaskan pejabat yang berwenang wajib memberikan perlindungan dan jaminan keamanan kepada pelapor sebagaimana dimaksud dalam Pasal 8 dan/atau orang yang menyerahkan pelaku sebagaimana dimaksud dalam Pasal 9. Tapi permasalahannya kembali kepada kepedulian dan kesadaran masyarakat juga, apakah masyarakat sudah mengetahui mengenai peransertanya dalam penegakan qanun-qanun syariah di Aceh.

Kesadaran hukum masyarakat tidak dapat dipisahkan dari intensitas disseminasi dan penyuluhan yang dilakukan para penyelenggara pemerintah daerah (Aceh) kepada masyarakat. Setiap penyelenggara negara berkewajiban memberikan penyuluhan hukum sebagai bagian dari proses edukasi dan pembudayaan hukum. Penyuluhan hukum merupakan tanggung jawab setiap penyelenggara negara. Kesadaran hukum masyarakat ini sebenarnaya bisa dibagun melalui bentuk/kegiatan sosialisi tentang qanun-qanun jinayat khususnya Qanun Nomor 14 Tahun 2003. Peran Kantor Dinas Syariat Islam³ (DSI) Kota

32 Wawancara dengan S (nama disamarkan) Warga Gampong Sikelang Kecamatan Penanggalan. HL (nama disamarkan) warga Gampong Rindeng, Kecamatan Rundeng. Wawancara dengan HM (nama disamarkan) warga Gampong Sigrun, Kec. Sultan Daulad. (27 Mei 2015).

33 Dinas Syariat Islam adalah perangkat daerah sebagai unsur pelaksana syariat Islam di lingkungan Pemerintah Daerah Aceh yang berada di bawah Gubernur. Pembentukan Dinas Syariat Islam di Aceh ini merupakan suatu bentuk tindak lanjut terhadap UU No. 44 tahun 1999 tentang Penyelenggaraan Keistimewaan Daerah Istimewa Aceh, untuk meningkatkan kelancaran pelaksanaan tugas operasional Pemerintah Provinsi Daerah Istimewa Aceh di bidang pelaksanaan 
Subulussalam dalam hal ini sangat di harapkan kontribusinya. Hotma Capah selaku Sekretasis DSI Kota Subulussalam menjelaskan bahwa, selama ini DSI telah berupa semaksimal mungkin dalam mensosialisasikan qanun syariat Islam di Aceh, mulai dari remaja-remaja masjid, tokoh masyarakat dan sekolah-sekolah. DSI Kota Subulussalam juga menghimbau kepada seluruh da'i perbatasan yang ada di gampong-gampong untuk ikut mensosialisasikan qanun-qanun syariat Islam di Aceh. ${ }^{34}$

Lain dengan keterangan pemerintah (DSI), masyarakat menilai bahwa sosialisasi yang dilakukan DSI sekarang ini masih disara sangat kurang. DSI Kota Subulussalam di nilai terkesan setengah hati dalam melakukan sosialisasi kepada masyarakat, terlebih-lebih Parlemen Aceh telah mengesahkan Qanun No 6/2014 tentang Hukum Jinayat pada 27 September 2014, lalu dimasukkan ke dalam lembaran daerah pada 23 Oktober 2014. Qanun itu baru bisa berlaku setelah setahun sejak pengesahan. Pemerintah diamanatkan untuk mensosialiasikan keberadaan Qanun Pidana itu ke segala lapisan masyarakat. DSI Kota Subulussalam dituntut untuk lebih giat lagi dalam melakukan sosialisasi semua qanun syariat Islam di Kota Subulussalah, sehingga asas fiksi hukum yang menganggap semua orang tahu hukum (presumptio iures de iure). Semua orang dianggap tahu hukum, tak terkecuali petani yang tak lulus sekolah dasar, atau warga yang tinggal di pedalaman. Dalam bahasa latin dikenal pula adagium ignorantia jurist non excusat, ketidaktahuan hukum tidak bisa dimaafkan. Seseorang tidak bisa mengelak dari jeratan hukum dengan berdalih belum atau tidak mengetahui adanya hukum dan peraturan perundang-undangan tertentu, ${ }^{35}$ dapat dijalankan ditengah-tegah masyarakat Kota ubulussalam. Dibutuhkan kesadaran yang tinggi dari masyarakat Kota Subulussalam untuk melaksanakan Syariat Islam, disamping itu juga harus adanya political will pemerintah dan peran serta stakeholders dan tentunya dilakukan secara bertahap atau gradual.

syariat Islam yang lebih efisien dan berolehguna, maka dipandang sangat perlu untuk membentuk susunan organisasi dan tata kerja Dinas Syariat Islam Provinsi Daerah Istimewa Aceh yang sesuai dengan karakteristik, potensi dan kebutuhan daerah. Lihat, Konsideran Peraturan Daerah Propinsi Daerah Istimewa Aceh No. 33 Tahun 2001 Tentang Pembentukan Susunan Organsasi Dan Tata Kerja Dinas Syariat Islam Propinsi Daerah Istimewa Aceh, Lembaran Daerah Propinsi Daerah Istimewa Aceh Tahun 2001 No. 65.

${ }^{34}$ Wawancara dengan Hotma Capah, selaku Sekretaris DSI Kota Subulussalam. 21 April 2015.

35 Hukum Online, "Fiksi Hukum Harus Didukung Sosialisasi Hukum", http://www. hukumonline.com/berita/baca/hol19115/fiksi-hukum-harus-didukung (diakses pada tanggal 25 Nov. 2015). 


\section{A. Pengawasan dan Pembinaan Terhadap Qanun Nomor 14 Tahun 2003}

Untuk meningkatkan efektivitas menerapan qanun ini, peran serta masyarakat sangat dibutuhkan, sama halnya dengan Qanun 12, 13 Tahun 2003 dimana masyarakat diberi peran dalam membantu upaya pencegahan dan pemberantasan perbuatan khalwat dengan kewajiban melapor kepada pejabat yang berwenang baik lisan maupun tulisan apabila masyarakat mengetahui adanya orang atau kelompok masyarakat yang melakukan pelanggaran terhadap larangan khalwat/mesum di Aceh. Guna untuk menjamin keamanan masyarakat yang melaporkan tindakan perlanggaran terhadap qanun khalwat/mesum, pejabat bewenang wajib memberikan perlindungan dan jaminan keamanan kepada masyarakat yang melapor. 36

Mengenai pengwasan dan pembinaan, penyidikan dan penuntutan sebagai mana tertera dalam bab V dan Bab VI Qanun Nomor 14 Tahun 2003 memiliki kandungan yang sama seperti dua qanun sebelumnya. Untuk melakukan pengawasan dan pembinaan terhadap pelaksanaan qanun ini, Gubernur, Bupati/Walikota membentuk Wilayatul Hisbah; Susunan dan kedudukan Wilayatul Hisbah diatur lebih lanjut dengan surat Keputusan Gubernur dan/atau Bupati/Walikota setelah mendengar pendapat Majelis Permusyawaratan Ulama. ${ }^{37}$

Dalam melaksanakan fungsi pengawasannya, Pejabat Wilayatul Hisbah sebagaimana dimaksud dalam pasal 13 bila menemukan pelaku pelanggaran terhadap larangan sebagaimana dimaksud dalam pasal 5 dan 6, menyampaikan laporan secara tertulis kepada penyidik; Dalam melaksanakan fungsi pembinaannya, Pejabat Wilayatul Hisbah yang menemukan pelaku jarimah khalwat/mesum dapat memberi peringatan dan pembinaan terlebih dahulu kepada pelaku sebelum menyerahkannya kepada penyidik; Pejabat Wilayatul Hisbah wajib menyampaikan laporan kepada penyidik tentang telah dilakukan peringatan dan pembinaan sebagaimana dimaksud dalam ayat (2). ${ }^{38}$

Menurut hemat penulis, pengawasan terhadap qanun pidana di Kota Subulussalam baik khamar, masir maupun khalwat selama ini memang belum begitu berjalan dengan baik. Hal ini bukan semata menajdi salah dari pemerintah saja, tetapi semua aspek tatanan kehidupan sosial kemasyarakatan di Kota Subulussalam, baik pemerintah maupun masyarakatnya. Kelemahan dalam melaukan penegakan dan pengawasan yang dilakukan pihak berwenag selama ini, seperti yang telah teridentifikasi di atas seperti keterbatasan

\footnotetext{
${ }^{36}$ Lihat Bab IV Pasal 8, 9 dan 10 Qanun Nomor 14 Tahun 2003.

37 Pasal 13 Qanun Nomor 14 Tahun 2003 Tentang Khalwat.

38 Pasal 13 Qanun Nomor 14 Tahun 2003 Tentang Khalwat.
} 
anggota $\mathrm{WH}$, sarana dan fasilitas, anggaran dan lainnya sebenarnya bisa disiasati dengan melibatkan peran serta masyarakat dalam menanggulangi terjadinya perbuatan khalwat (mesum) di Kota Subulussalam. Peran masyarakat inilah yang dirasakan masih kurang selama ini dalam proses penegakan qanun-qanun jinayat di Kota Subulussalam. ${ }^{39}$ Untuk meningkatkan pengawasan terhadap pemberlakuan Qanun Nomor 14 Tahun 2003 di Kota Subulussalam, ada beberapa hal yang harus di perhatikan pemerintah sebagai berikut:

\section{Melibatkan Peran Aktif Masyarakat di Gampong-gampong}

Peran aktif masyarakat memang sangat di harapkan dalam penerapan setiap qanun di Aceh, begitu juga halnya dengan qanun khalwat yang diatur dalam Qanun 14 Tahun 2003. Pemerintah dalam hal ini Dinas Syariat Islam dan Wilayatul Hisbah sudah saatnya meningkatkan hubungan dengan masyarakat dan khususnya para tokoh masyarakat di tiap-tiap gampong yang ada di Kota Subulussalam dan menjadikan mereka menjadi salah unsur pengawas utama setiap qanun di gampongnya masing-masing. Kenapa harus menjadikan tokoh masyarakat gampong menjadi pengawas utama dalam penegakan Qanun Nomor 14/2003? Hal ini dikarenakan para tokoh masyarakat gampong pada dasarnya sangat disegani dan para pelaku khalwat diharapakan berpikir berulangkali ketika hendak melakukan perbuatan yang bertentangan dengan ketentuan Qanun Nomor 14 Tahun 2003. Jika tiap-tiap gampong telah diterapkan sistem pengawasan yang seperti itu, maka prilaku menyimpang masyarakat khususnya khalwat dapat di tekan ketitik yang paling rendah.

Selama ini peran masyarakat bukan berarti tidak ada, hanya saja peran masyarakat sangat sulit diwujudkan, karena tidak memiliki ruang yang legal dan tidak memiliki wewenang formal yang dapat dipertanggung jawabkan. ${ }^{40}$ Dengan demikian apabila ada kontrak kerja antara pemerintah dan tokoh masyarakat gampong, maka di harapkan peran masyarakat tersebut dapat teraktualisasi di lapangan.

\section{Megaktifkan Remaja Masjid}

Masa remaja adalah masa yang paling rentan, karena pada masa-masa seperti ini anak yang baru menuju kepada dewasa sering mencari tau tentang jati dirinya di tengahtengah masyarakat. Maka untuk itu perlu adanya suatu konsep dan sistem yang

39 Wawancara dengan Ust. H. Qaharuddin Kombih, selaku Ketua MPU Kota Subulussalam (20 April 2015).

40 Abubakar dan Anwar, "Strategi dan Hambatan Penerapan Qanun Khalwat dalam Pencegahan Prilaku Khalwat pada Remaja Kota Banda Aceh", JURNAL PENDIDIKAN SERAMBI ILMU, 2011.68-90. 
memusatkan pencegahan penyimpangan syariat Islam pada remaja. Remaja masjid dipandang sebagai suatu sarana/sistem dalam membentuk karakter para para remaja, sehingga dengan adanya kegiatan keremajaan di masjid di harapkan dapat memberi pengetahuan yang baik tentang keislaman itu sendiri kepada setiap remaja.

\section{Kerjasama Dengan Pengusaha Seperti Hotel dan Cafe}

Perbuatan khalwat yang terjadi di Kota Subulussalam kebanyakan terjadi di Hotel (penginapan) dan cafe-cafe yang tersebar di Kota Subulussalam, seperti contoh kasus bahwa pelaku khalwat di tangkap di sebuah penginapan di kawasan Penanggalan dan di salah satu cafe di bantaran Lae Kombih. Maka untuk itu pemerintah seharusnya menjalin kerjasama dengan para pengusaha tersebut supaya tidak memberikan fasilitas kepada mereka yang melakukan perbuatan yang bertentangan dengan Qanun Aceh.

\section{Membuat Pos Pengamanan WH}

Seperti yang telah dijelaskan pada bab sebelumnya, bahwa salah satu kelemahan WH dalam mengawasi pemberlakuan Qanun 14/2003 adalah dikarenakan keterpusatan kantor WH yang hanya ada di pusat kota Subulussalam, walupun sebenarnya idealnya kantor WH ada di setiap kecamatan di Kota Subulussalam, tapi karena angggaran yang terbatas, maka untuk saat ini pemerintah seharusnya membentuk pos-pos pengawasan WH di setiap kecamatan, mengingat antar kecamatan di Kota Subulussalam sangat berjauhan secara geografis dan hal ini dianggap sangat efektif karena anggaran yang dibutuhkan juga tidak terlalu besar.

\section{Kesimpulan}

Dari penjelasan di atas dapat diambil satu kesimpulan besar bahwa banyak faktor yang melatarbelakangi kurang efektifnya pemberlakuan qanun jinayat di Kota Subulussalam khususnya terhadap Qanun No. 14 Tahun 2003 tentang khalwat, baik dari segi faktor hukum maupun faktor non-hukum. Kedua faktor tersebut tentu saling bertalian satu sama lain yang diharapkan dapat segera meneukan formulasi yang tepat untuk mengatasi masalah-maslaah tersebut.

Mengenai adanya dualisme dalam penanganan kasus khalwat di Aceh memang menjadi polemik tersendiri bagi para penegak qanun syariah di Aceh (wilayatul hisbah). Sudah seharusnya para pemangku kepentingan duduk bersama untuk menentukan batasan dan kadar khalwat seperti apa dan bagaimana yang dapat diselesaikan melalui Mahkamah 
Adat Aceh dan Mahkamah Syar'iyah. Seperi yang sudah dijelaskan di atas bahwa tindak pidana khalwat (mesum) tidak semuanya bisa dilimpahkan ke mahkamah syar'iyah. Ada beberapa faktor yang mempengaruhinya, antara lain:

1. Karena proses hukumnya di selesaikan secara hukum adat berdasarkan kekeluargaan dengan cara menikahkan pelaku khalwat (mesum), membayar denda dan perdamaian;

2. Karena adanya tuntutan dari masyarakat untuk diselesaikan secara damai melalui hukum yang berlaku dalam masyarakat dengan cara mendidik dan membimbing masyarakat yang telah berbuat khalwat (mesum);

3. Karena perbuatan khalwat (mesum) yang dilakukan hanya bersifat ringan dan sedang, kecuali khalwat (mesum) yang sifatnya berat.

Di Aceh disamping adanya lembaga hukum formal yang menangani pelanggaran syariat Islam, juga terdapat lembaga informal yaitu lembaga adat yang sangat berpengaruh pada pola kehidupan masyarakat Aceh. Lembaga adat memiliki landasan hukum yakni Qanun No. 9 Tahun 2008 tentan Pembinaan Kehidupan Adat dan Adat Istiadat serta Qanun Nomor 10 Tahun 2008 tentang Lembaga Adat. Dengan demikian, hukum adat yang berlaku dalam masyrakat merupakan salah satu hukum yang membentengi hukum-hukum yang lainnya. Walaupun hukum adat tidak betentangan dengan hukum-hukum atau peraturan perundang-rundangan yang lain yang dibuat oleh pemeintah, karena tujuan hukum adat mendidik masyarakat dengan jalan menasehati dan membimbing masyarakat untuk kembali kepada jalan yang benar, tapi pada kenyataannya hukum adat sedikit banyaknya telah mempengaruhi proses penerapan hukum Islam di Aceh seperti halnya kasus khalwat.

\section{PUSTAKA RUJUKAN}

Abu Bakar, Al Yasa'. "Islam, Hukam dan Masyarakat di Aceh Tajdid Syariat dalam Negara Bangsa", First International Conference of Aceh and Indian Ocean Studies, 24-27 Februari 2007.

Abu Bakar, Al Yasa'. Wilayatul Hisbah, Polisi Pamong Praja Dengan Kewenangan Khusus di Aceh. Banda Aceh: Dinas Syari' at Islam Aceh, 2009.

Abubakar dan Anwar. "Strategi dan Hambatan Penerapan Qanun Khalwat dalam Pencegahan Prilaku Khalwat pada Remaja Kota Banda Aceh". JURNAL PENDIDIKAN SERAMBI ILMU, 2011.

Ali, Jainuddin. Sosiologi Hukum. Jakarta: Sinar Grafika, 2007. 
Bahri, Syamsul. "Pelaksanaan Syariat Islam di Aceh Sebagai Bagian dari Wlayah NKRI". Jurnal Dinamika Hukum Vol. 12 No. 2 Mei 2012.

Basri, Hasan. "A. Hasjmy (1914-1998) Kajian Sosial-Intlektual Pemikiran Tentang Politik Islam".

Disertasi Sps UIN Jakarta, 2008.

Danial. “Efektifitas 'Uqūbat Dalam Qanun No. 14/ 2003 dan DQHR Tentang Khalwat dan Ikhtilath, "Jurnal Asy-Syir'ah" Vol. 45, No. I, 2011.

Hukum Online, Fiksi Hukum Harus Didukung Sosialisasi Hukum, http://www. hukumonline.com/berita/baca/hol19115/fiksi-hukum-harus-didukung (diakses pada tanggal 25 Nov. 2015).

Jack, Hirwan. "Efektivitas Wilayatul Hisbah Dalam Pencegahan Aliran Sesat Di Aceh", http://bkpp.acehprov .go.id/ simp egbrr /Art ikel/Artikel05-02-2015/Wilayatul H i s bah_Aceh.pdf , 2. (diakses pada tanggal 16/03/2015).

Keputusan Gubernur Aceh No. 01 tahun 2004 tentang kewenangan pembentukan Organisasi Wilayatul Hisbah.

Konsideran Peraturan Daerah Propinsi Daerah Istimewa Aceh No. 33 Tahun 2001 Tentang Pembentukan Susunan Organsasi Dan Tata Kerja Dinas Syariat Islam Propinsi Daerah Istimewa Aceh, Lembaran Daerah Propinsi Daerah Istimewa Aceh Tahun 2001 No. 65.

Lubis, zulkarnain. Menyambut Qanun Jinayah Nomor 6 Tahun 2014, https://drive. google. Com/file/d/0B5UQVcJ8Df8WenBNSWNfZU VMcTQ/view? pli=1 (diakses 20 Oktober 2015).

Mansur, Teuku Muttaqin. Penyelesaian Kasus Mesum Melalui Mahkamah Adat atau Mahkamah Syar'iyah?, http://aceh.tribunnews.com/2013/09/04/peny elesaiankasus-mesum-melalui-ma-atau-ms?page=3 (dikases pada tanggal 24 Agustus 2015).

Muhammad, Rusjdi Ali. Revitalisasi Syari'at Islam di Aceh: Problem, Solusi dan Implementasi. Ciputat: Logos Wacana Ilmu,2003.

Nasir, Haedar. Islam syariat: Reproduksi Salapiyah Idiologis di Indonesia. Bandung: Mizan 2013. Putri Sahadat Bancin, Penyelesaian Tindak Pidana Khalwat/Mesum Berdasarkan Qanun Nomor 14 Tahun 2003 (Suatu Penelitian Di Kota Subulussalam). Banda Aceh: Skripsi Fak. Hukum Univ. Syiah Kuala, 2015.

Qanun No. 9 Tahun 2008 tentan Pembinaan Kehidupan Adat dan Adat Istiadat.

Qanun Nomor 10 Tahun 2008 tentang Lembaga Adat.

Santoso, Topo. Membumikan Hukum Pidana Islam: Penegakan Syariat dalam Wacana dan Agenda. Jakarta: GIP, 2003. 
Soekanto, Soerjono. Faktor-Faktor yang Mempengaruhi Penegakan Hukum. Jakarta: PT. Raja Grafindo Persada, 2008.

Uddin, Asma. "Religious Freedom Implications of Sharia Implementation in Aceh, Indonesia," University of St. Thomas Law Journal: Vol. 7: Iss. 3 (2010).

Zada, Khamami. "Sentuhan Adat Dalam Pemberlakuan Syariat Islam di Aceh (1514-1903)", Karsa, Vol. 20 No. 2, Desember 2012. 